\title{
Clearance of bacteria-sized particles by natural populations of nanoplankton in the Chesapeake Bay outflow plume
}

\author{
George B. McManus ${ }^{1}$, Jed A. Fuhrman ${ }^{2}$ \\ ${ }^{1}$ Institute of Ecosystem Studies, Box AB, Millbrook, New York 12545, USA \\ ${ }^{2}$ Marine Sciences Research Center, SUNY Stony Brook, New York 11794, USA
}

\begin{abstract}
The uptake of bacteria-sized particles by non-pigmented nanoplankton was measured in late winter (February) and spring (June) in the Chesapeake Bay outflow plume. Small flagellates (11 to $35 \mu^{3}$ average cell volume) numerically dominated the grazer community in both seasons, although expenments in June showed that ciliates could also be important bacterivores. Rates of ingestion ranged from 1.8 to 25.0 bacteria flagellate ${ }^{-1} \mathrm{~h}^{-1}$ and were significantly correlated with bacterial abundance. Specific clearance rates (body volumes swept clear per hour) of these natural populations of flagellates were similar to those of forms which have been studied in culture. Flagellate community clearance rates were similar to bacterial growth rates in February. In June, however, grazing was much lower than growth, and flagellates removed, on average, only $23 \%$ of daily bacterial production. Reasons for this shortfall possibly include other sources of bacterial mortality, discrimination by grazers against the particles, the omission from the grazing measurement of larger, rarer bacterivores (e.g. ciliates), and artifacts resulting from particle egestion.
\end{abstract}

\section{INTRODUCTION}

Several techniques have been used to estimate predatory mortality of bacterioplankton, including separation of bacteria from their predators by dilution (Landry et al. 1984, Ducklow \& Hill 1985) or filtration (Gak et al. 1972, Wright \& Coffin 1984a,b, Rassoulzadegan \& Sheldon 1986), and the use of radiolabelled bacteria as a tracer (Hollibaugh et al. 1980, Lessard \& Swift 1985, Wikner et al. 1986). Recently, some investigators have used fluorescent particles (FP) and fluorescence microscopy to study ingestion in natural populations of bacterivores (Børsheim 1984, Bird \& Kalff 1986, McManus \& Fuhrman 1986, Pace \& Bailiff 1987). These particles can be observed inside organisms that have ingested them, and clearance rates can be calculated from time courses of uptake. Fluorochrome-stained bacteria have also been used in this way (Sherr \& Sherr 1987, Sherr et al. 1987).

We performed a series of field experiments using the fluorescent particle technique to estimate grazing as part of the MECCAS (Microbial Exchanges and Coupling in Coastal Atlantic Systems) project, a multidisciplinary investigation of microbial production processes

(c) Inter-Research/Printed in F. R. Germany in the outflow plume of Chesapeake Bay. The plume, a mesoscale $\left(<2000 \mathrm{~km}^{2}\right)$ hydrographic feature, is characterized by lower salinity ( 22 to $30 \%$ ) and higher productivity than the surrounding continental shelf waters (Boicourt et al. 1987).

Uptake of fluorescent pigment particles was used to determine: (1) whether natural populations of heterotrophic microflagellates would ingest the particles and how their clearance rates would compare to those of laboratory-studied forms; (2) whether the technique could provide information on the dependence of bacterivory upon temperature, bacterial concentration or other factors; (3) the degree to which grazing by heterotrophic nanoplankton could account for bacterial production; and (4) whether bacterivory by other protozoa, especially ciliates, could account for a significant fraction of the total bacterivory.

\section{MATERIALS AND METHODS}

Most of the experiments reported here were performed during drogue studies in the plume (operationally defined by the $30 \%$ surface isohaline) in February 
and June 1985. One experiment was performed at an offshore station (Stn 157; Table 1). Surface samples ( $1 \mathrm{~m}$ depth) were taken with $30 \mathrm{l}$ PVC Niskin bottles which were subsequently drained into polyethylene carboys and used for experiments. Subsamples of $50 \mathrm{ml}$ were poured into sterile whirlpak bags and fluorescent pigment particles were added from a stock suspension containing approximately $10^{8}$ particles $\mathrm{ml}^{-1}$. This stock suspension was prepared as described previously (McManus \& Fuhrman 1986) using commercially available fluorescent pigments (Radiant Color Co.i Richmond, California, USA) added to filtered seawater and then passed through a $1.0 \mu \mathrm{m}$ pore-size Nuclepore filter to remove larger particles. For the June experiments the dry pigment particles were first suspended in a solution of bovine serum albumen to help disperse them (Pace \& Bailiff 1987).

To ensure that only the linear portion of the uptake curve was used for grazing rate calculations, the bags were subsampled 4 or 5 times during short incubations (25 to $45 \mathrm{~min}$ ). At each sampling time $10 \mathrm{ml}$ was removed with a plastic pipette and preserved in $1 \%$ (final concentration) glutaraldehyde. Slides for epifluorescence microscopy were made immediately at the end of the experiment using $0.8 \mu \mathrm{m}$ pore-size irgalan black-stained Nuclepore filters and the fluorochrome proflavine (Haas 1982). Between 3 and $10 \mathrm{ml}$ were stained (1.65 $\mu \mathrm{g} \mathrm{ml} \mathrm{m}^{-1}$ proflavine; $4 \mathrm{~min}$ ) and collected on the filters, which were then mounted on glass slides in Cargille's type $\mathrm{A}$ immersion oil and stored frozen and dark until they could be counted. Slides that were not counted immediately were stored at $-20^{\circ} \mathrm{C}$ to ensure that the chlorophyll autofluorescence of photosynthetic flagellates would be preserved (Bloem et al. 1986).

Subsamples of 1 or $2 \mathrm{ml}$ from each experiment were stained with acridine orange (Hobbie et al. 1977) for enumeration of bacterioplankton and pigment particles to determine 'specific activity' (FP/[FP + bacteria]) and bacterioplankton concentration. These slides were counted under blue light excitation (FP + bacteria) and under ultraviolet light excitation (FP only) because acridine orange fluoresces only weakly under UV light while the pigment particles fluoresce quite strongly.

To count the proflavine-stained slides, blue excitation and a flat field objective were used with a total magnification of $1250 \times$ Cells which had a definite shape and a stained nucleus but did not contain fluorescing chloroplasts were counted as heterotrophic nanoplankton (HNAN). The great majority of these were flagellates. Ciliate bacterivory was measured separately on 2 occasions. Ciliates were located on the filter at low magnification $(500 \times)$ and examined at $1250 \times$ for ingested particles.

For the February data $\left(T=5\right.$ to $7^{\circ} \mathrm{C}$ ), least squares regression lines used to calculate ingestion included all points, since uptake appeared to be linear for up to $45 \mathrm{~min}$. For the June data, $\left(\mathrm{T}=20\right.$ to $\left.24^{\circ} \mathrm{C}\right)$, points between $t=20$ and 25 min which fell below the regression line were omitted, as were all points beyond 25 min. Earlier observations (McManus \& Fuhrman 1986) had indicated that uptake would begin to depart from linearity after 20 to $40 \mathrm{~min}$ at $20^{\circ} \mathrm{C}$.

A certain amount of imprecision is unavoidable at the lower end of the uptake curve, when the number of particles ingested per flagellate may be 0.1 or less. In those cases examining even a very large portion of the filter, and counting 200 or more flagellates, can still produce anomalous uptake values because a few flagellates with several particles each can substantially alter the average. For this reason the use of a single end point determination for uptake was deemed insufficient, and 3 or 4 point time courses were always used to estimate ingestion.

To obtain an ingestion rate from the regressions, the slopes (in units of FP ingested per HNAN per hour) were divided by the specific activity to give total particles (bacteria + FP) per HNAN per hour. Ingestion rate was divided by the total abundance of particles (FP + bacteria) to calculate clearance (volume of water cleared of food particles per HNAN per hour). Specific clearance, body volumes cleared of food particles per HNAN per hour, was also calculated. This is a useful parameter for comparisons among organisms of different sizes and different filtering mechanisms (Fenchel 1984).

Separate subsamples from the same carboys were examined to enumerate flagellates, measure cell dimensions, and determine the percentage of flagellates associated with large particles or aggregates.

Bacterioplankton production estimates were based on thymidine incorporation using a conversion factor of $2 \times 10^{18}$ cells per mole thymidine incorporated (Fuhrman \& Azam 1982).

Temperature, particle concentration, average flagellate cell volume, percentage of flagellates associated with particles or aggregates, and bacterioplankton specific growth rate were tested for ability to predict the dependent variable ingestion rate using multiple regression analysis (Sokal \& Rohlf 1969).

\section{RESULTS}

In Fig, 1 the results of 2 typical time courses of particle uptake are shown, one from February and one from June. The linearity of uptake was good over the range of points used in the regressions. Coefficients of determination $\left(\mathrm{r}^{2}\right)$ ranged from 0.763 to 0.996 . Ingestion appeared to be a linear function of food particle con- 
centration for the February cruise (Fig. $2 \mathrm{~A}_{i} \mathrm{r}^{2}=0.83 ; \mathrm{p}$ $<0.01$ ). Clearance, on the other hand, remained nearly constant with increased particle concentration (Fig. $2 \mathrm{~B})$. For June there was no consistent pattern of increase in ingestion rate at increasing food particle concentrations (Fig. 3A.). At very high concentrations a 5 -fold range of ingestions, from 4.4 to 24.9 bacteria HNAN $^{-1} \mathrm{~h}^{-1}$, was observed. Clearance was also variable at high concentrations (Fig. 3B). Although the 3 lowest values for clearance for the entire study were all observed in June at concentrations exceeding $7.5 \times 10^{9}$ cells $1^{-1}$, several of the highest values for clearance were also found in this concentration range. When all of the ingestion data are plotted on the same axes (Fig. 4), the general trend for increasing ingestion rate with increasing concentration can be seen amid the considerable scatter at high concentrations $\left(\mathrm{r}^{2}=0.51 ; \mathrm{p}\right.$ $<0.01$ ).

Grazing and growth data from the 17 shipboard

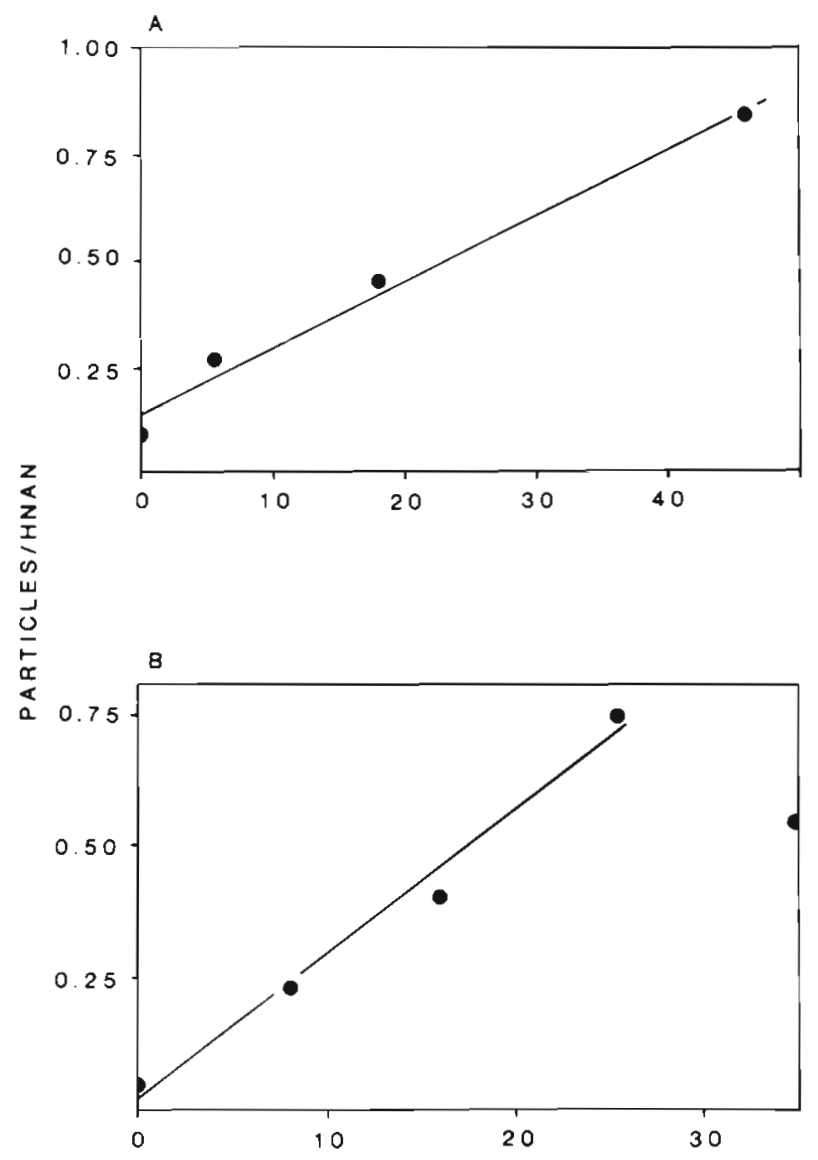

MINUTES

Fig. 1. Time courses and regression lines for 2 typical particle uptake experiments. (A) February (Stn 38); (B) June (Stn 99) experiments are summarized in Table 1. During February, the heterotrophic flagellate community filtered 8.2 to $16.0 \%$ of the water clear of bacteria on a daily basis. These numbers were equal to or greater than bacterial growth rates. In June bacterial populations and growth rates were higher, and flagellate populations were slightly lower The range of community clearance rates was greater, from 1.1 to $19.4 \%$ of the water cleared per day. Generally, these values were lower than in February, and except for Stn 49, where grazing nearly equalled bacterial growth, grazing by microflagellates was calculated to remove only 5 to $26 \%$ of measured bacterial production.

The results of the 2 experiments in which ciliate particle uptake was measured are shown in Fig. 5A, B. At Stn 215, near the mouth of the bay, ciliate ingestion was much higher ( 369 bacteria ciliate ${ }^{-1} \mathrm{~h}^{-1}$ ) than at Stn 49 (66 bacteria ciliate ${ }^{-1} \mathrm{~h}^{-1}$ ) farther out on the shelf.
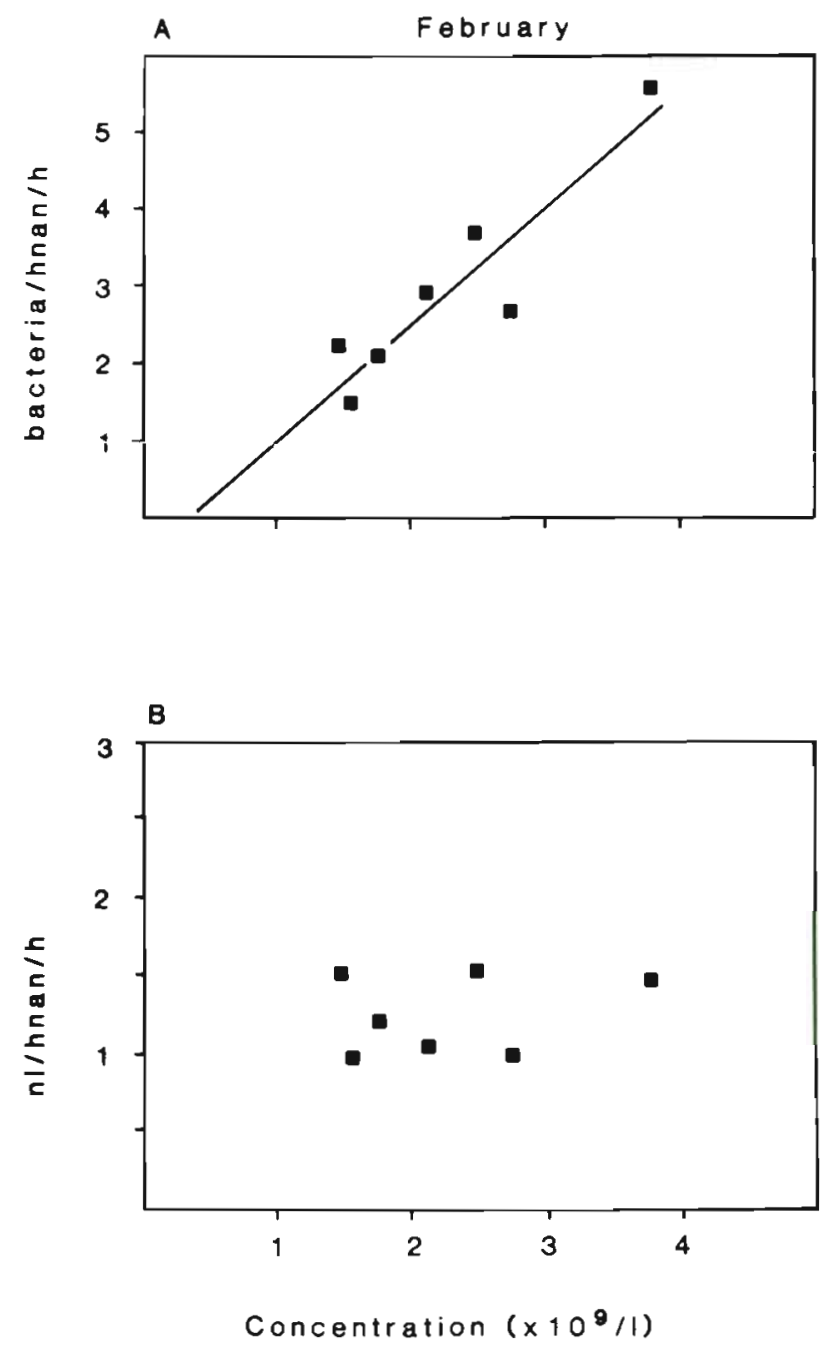

Fig. 2. (A) Ingestion and (B) clearance as a function of concentration (FP + bacteria) during February 

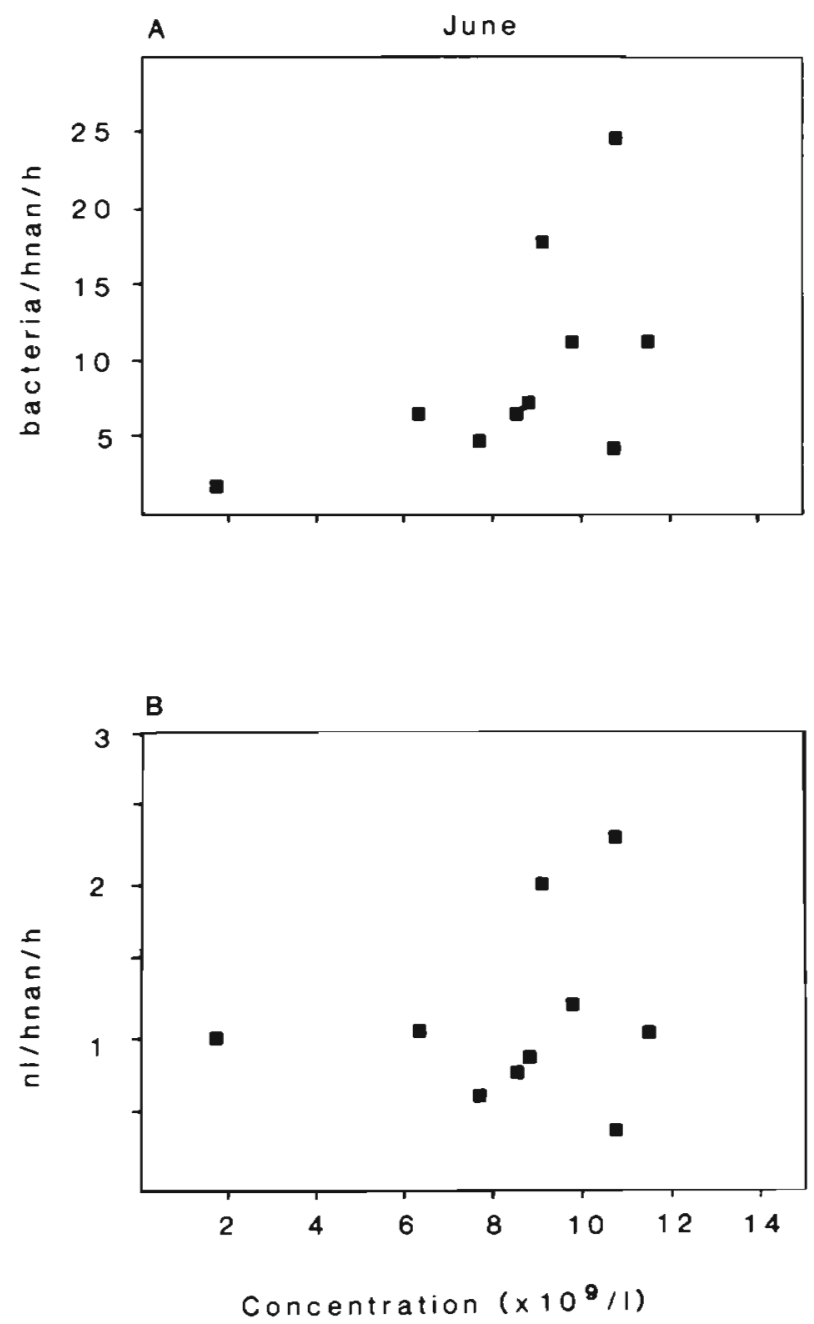

Fig. 3. Same as Fig. 2, except data from June

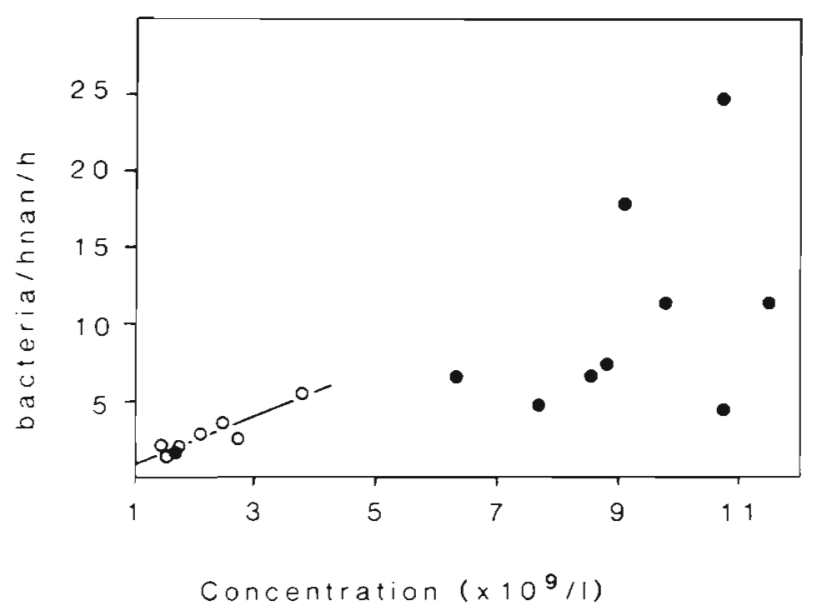

Fig. 4. Ingestion vs concentration; all data. (o) February; June

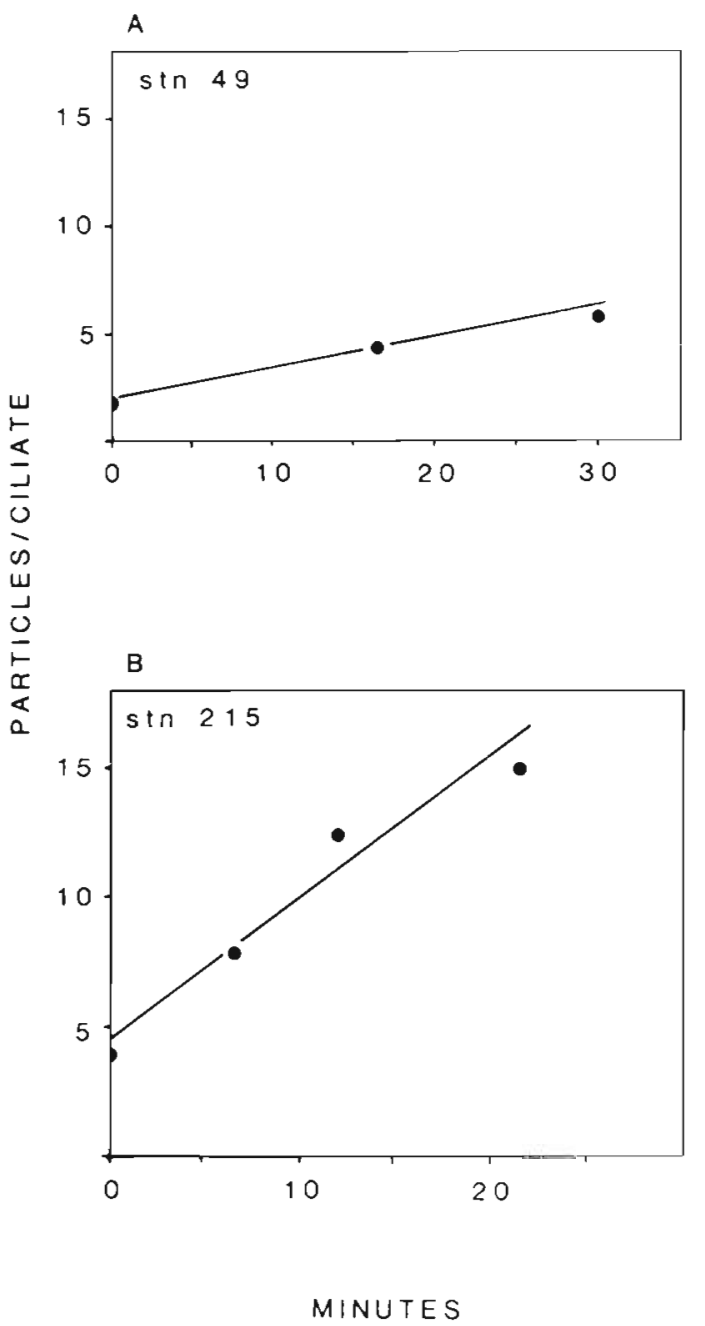

Fig. 5. Fluorescent particle uptake by ciliates at 2 stations in June. (A) Stn 49; (B) Stn 215

Protozoan biomass, but not number, was dominated by oligotrichs, tintinnids, and small unidentified ciliates at Stn 215. Ciliates were less abundant at Stn 49, although they still represented a substantial portion of the protozoan biomass. When the ciliate ingestion rates are included, the overall grazing increases by $67 \%$ for Stn 215 and only $2 \%$ for $\operatorname{Stn} 49$.

\section{DISCUSSION}

Fenchel (1980a, 1982) used Michaelis-Menten kinetics to describe the functional response of filter feeders to changes in food concentration. He reasoned that at low concentrations ingestion is limited by the maximum rate at which water can be filtered and at high concentrations the uptake rate is saturated because 
Table 1 Summary of results from 17 grazing assays using fluorescent particles

\begin{tabular}{|c|c|c|c|c|c|c|c|c|c|c|c|}
\hline Stn & Lat. & Long. & $\begin{array}{c}\mathrm{T} \\
\left({ }^{\circ} \mathrm{C}\right)\end{array}$ & $\begin{array}{c}S \\
(\%)\end{array}$ & $\begin{array}{l}\text { Bacteria } \\
\left(\times 10^{9} 1^{-1}\right)\end{array}$ & $\begin{array}{l}\text { Sp. } \\
\text { act. }^{1}\end{array}$ & $\begin{array}{l}\text { Hetero- } \\
\text { trophic } \\
\text { flagel- } \\
\text { lates } \\
\left(\times 10^{6} l^{-1}\right)\end{array}$ & $\begin{array}{c}\text { Clearance } \\
\left(\text { nl flag }{ }^{-1} \mathrm{~h}^{-1}\right)\end{array}$ & $\begin{array}{l}\text { Specific } \\
\text { clear- } \\
\text { ance } \\
\left(\times 10^{4} h^{-1}\right)\end{array}$ & $\begin{array}{l}\text { Growth } \\
\left(\mathrm{d}^{-1}\right)\end{array}$ & $\begin{array}{c}\text { Grazing } \\
\left(\mathrm{d}^{-1}\right)\end{array}$ \\
\hline \multicolumn{12}{|c|}{ February } \\
\hline 35 & $36^{\circ} 56^{\prime} \mathrm{N}$ & $75^{\circ} 47^{\prime} \mathrm{W}$ & 7.5 & 26.09 & 1.88 & 0.11 & 3.30 & 1.05 & 2.98 & 0.077 & 0.083 \\
\hline 36 & $36^{\circ} 53^{\prime} \mathrm{N}$ & $75^{\circ} 44^{\prime} \mathrm{W}$ & 5 & & 1.40 & 0.20 & 3.00 & 1.21 & 3.79 & 0.076 & 0.087 \\
\hline 38 & $36^{\circ} 46^{\prime} \mathrm{N}$ & $75^{\circ} 50^{\prime} \mathrm{W}$ & 5 & 25.45 & 1.77 & 0.35 & 3.71 & 0.99 & 5.30 & 0.076 & 0.088 \\
\hline 40 & $36^{\circ} 45^{\prime} \mathrm{N}$ & $75^{\circ} 52^{\prime} \mathrm{N}$ & 5 & 25.80 & 3.51 & 0.07 & 3.30 & 1.47 & 8.60 & 0.052 & 0.116 \\
\hline 41 & $36^{\circ} 44^{\prime} \mathrm{N}$ & $75^{\circ} 53^{\prime} \mathrm{N}$ & 5 & 25.58 & 1.10 & 0.25 & 3.57 & 1.52 & 8.09 & 0.194 & 0.130 \\
\hline 43 & $36^{\circ} 42^{\prime} \mathrm{N}$ & $75^{\circ} 54^{\prime} \mathrm{N}$ & 5 & 25.27 & 2.16 & 0.13 & 4.36 & 1.53 & 7.58 & 0.098 & 0.160 \\
\hline 76 & $36^{\circ} 59^{\prime} \mathrm{N}$ & $75^{\circ} 37^{\prime} \mathrm{N}$ & 5 & 28.40 & 1.13 & 0.27 & 3.48 & 0.98 & 6.13 & 0.086 & 0.082 \\
\hline \multicolumn{12}{|l|}{ June } \\
\hline 49 & $36^{\circ} 55^{\prime} \mathrm{N}$ & $75^{\circ} 41^{\prime} \mathrm{W}$ & 23 & 28.39 & 9.14 & 0.15 & 3.52 & 2.30 & 13.95 & 0.199 & 0.194 \\
\hline 60 & $36^{\circ} 58^{\prime} \mathrm{N}$ & $75^{\circ} 30^{\prime} \mathrm{W}$ & 23 & 29.71 & 6.45 & 0.16 & 0.77 & 0.62 & 4.84 & 0.140 & 0.012 \\
\hline 99 & $36^{\circ} 52^{\prime} \mathrm{N}$ & $75^{\circ} 44^{\prime} \mathrm{W}$ & 24 & 27.25 & 9.88 & 0.14 & 1.69 & 1.03 & 5.26 & 0.165 & 0.042 \\
\hline 105 & $37^{\circ} 00^{\prime} \mathrm{N}$ & $75^{\circ} 49^{\prime} \mathrm{W}$ & 21 & 28.52 & 9.22 & 0.14 & 1.84 & 0.40 & 2.23 & 0.230 & 0.018 \\
\hline 157 & $36^{\circ} 55^{\prime} \mathrm{N}$ & $74^{\circ} 27^{\prime} \mathrm{W}$ & 24 & 35.34 & 1.47 & 0.14 & 0.47 & 1.00 & 5.38 & - & 0.011 \\
\hline 205 & $36^{\circ} 55^{\prime} \mathrm{N}$ & $75^{\circ} 54^{\prime} \mathrm{W}$ & 21 & 28.21 & 7.27 & 0.15 & 1.75 & 0.77 & 3.19 & 0.240 & 0.032 \\
\hline 215 & $37^{\circ} 04^{\prime} \mathrm{N}$ & $76^{\circ} 06^{\prime} \mathrm{W}$ & 21 & 26.33 & 8.33 & 0.09 & 1.27 & 2.00 & 12.56 & - & 0.061 \\
\hline 216 & $36^{\circ} 54^{\prime} \mathrm{N}$ & $75^{\circ} 55^{\prime} \mathrm{W}$ & 21 & 28.68 & 8.90 & 0.09 & 1.34 & 1.21 & 5.08 & 0.371 & 0.039 \\
\hline 227 & $36^{\circ} 53^{\prime} \mathrm{N}$ & $75^{\circ} 52^{\prime} \mathrm{W}$ & 22 & 28.39 & 7.84 & 0.11 & 1.14 & 0.87 & 3.70 & 0.178 & 0.024 \\
\hline 235 & $36^{\circ} 56^{\prime} \mathrm{N}$ & $75^{\circ} 50^{\prime} \mathrm{W}$ & 20 & 28.58 & 5.06 & 0.20 & 1.05 & 1.04 & 5.48 & 0.523 & 0.026 \\
\hline
\end{tabular}

ingestion is limited by the time it takes the organism to process an individual food particle. The MichaelisMenten function provides a good fit to laboratory data for pure cultures of ciliates and flagellates (Fenchel 1980a, b, 1982). Data for natural populations from the present study do not permit discrimination between a saturation model and one of increasing ingestion rate with increasing concentration because a wide range of ingestion rates was observed at high bacterial concentrations. Highest ingestion rates were measured at the

Table 2. Values of $\mathrm{K}$, the Michaelis-Menten half-saturation concentration for ingestion, for 6 species of heterotrophic flagellates, compared to the range of bacterial concentrations from the present study. Calculated from Fenchel (1982), Table 1

\begin{tabular}{|lc|}
\hline Species & $\begin{array}{c}\mathrm{K} \\
\end{array}$ \\
\hline Monosiga sp. & $1 \times 10^{9}$ bacteria $\left.^{-1}\right)$ \\
Paraphysomonas vestita & 14.5 \\
Actinomonas mirabilis & 1.4 \\
Ochromonas sp. & 19.0 \\
Pleuromonas jaculans & 38.6 \\
Pseudobodo tremulans & 8.4 \\
Range during present study & 1. 1.-3. 5. (Feb) \\
& 1.5.-9.9. (Jun) \\
\hline
\end{tabular}

highest bacterial concentrations, however, and it may be that concentration determines the maximum possible ingestion rate, with other factors controlling the realized rate.

Although nearly all of the experiments were performed on 'plume' water (salinity <30\%o) during drogue studies, variations in species composition of the flagellate communities may have led to a departure from the kind of functional response one might find in a monospecific laboratory population. Kinetic parameters vary substantially from species to species, and mixtures of different species would probably show even greater variations in combined kinetic parameters (Williams 1973). Most of Fenchel's (1982) values for the Michaelis-Menten half-saturation constant are equal to or greater than the concentrations encountered in the present study (Table 2) so if the laboratory populations are representative of those found in nature, saturation of ingestion would not have been expected.

Total particle concentration was the only variable we tested that explained a significant fraction of the variance in ingestion rates $(0.025<\mathrm{p}<0.05)$. Accounting for temperature differences did not significantly reduce variance, despite the fact that the range of temperatures encountered $\left(5\right.$ to $\left.24^{\circ} \mathrm{C}\right)$ was great, and temperature is a strong determinant of physiological rates generally. Although most low ingestion rates 
Table 3. Comparison of ingestion and clearance data from the present study with that of Fenchel (1982), excluding data on Actinomonas mirabilis, which is specialized to feed on particles larger than 1 to $2 \mu \mathrm{m}$ in diameter (Fenchel 1984)

\begin{tabular}{|lll|}
\hline Parameter & Present study & Fenchel (1982) \\
\hline Bacteria flagellate $\mathrm{h}^{-1}$ & $1.8-25$ & $27-254(\mathrm{maximum})$ \\
Average flagellate volume & $11-35 \mu \mathrm{m}^{3}$ & $20-200 \mu \mathrm{m}^{3}$ \\
Specific clearance $\left(\times 10^{4} \mathrm{~h}^{-1}\right)$ & $2.2-14.0$ (mean 6.1$)$ & $5.2-11(\mathrm{mean} 8.1)$ \\
\hline
\end{tabular}

were associated with the lower temperatures of the February cruise (Fig. 4), bacterial concentrations were also lower then. In fact, for the only June experiment whose bacterial concentration fell into the range of the February experiments (Stn 157, offshore of the plume; see Fig. 4) the ingestion rate fell on the same line as that describing the colder water experiments (Fig. 2). It is possible that different communities of flagellates, adapted to different temperature regimes, can maintain similar rates of ingestion. While the epifluorescence technique used to enumerate them provides little information on the taxonomic composition of flagellate communities, some differences were observed between February and June. For example, in February, when overall flagellate populations were slightly higher, choanoflagellates comprised 8 to $35 \%$ of the total abundance $($ mean $=25.7 ; \mathrm{SE}=3.4 ; \mathrm{n}=7)$; for the June experiments they were only 0 to $10 \%($ mean $=5.7$; $\mathrm{SE}=1.0 ; \mathrm{n}=12$ ). These forms have a sieving mechanism that enables them to take particles as small as $0.2 \mu \mathrm{m}$ in size and may allow them to ingest even the very smallest bacteria (Fenchel 1984). Their decline between February and June is unexplained, but has also been observed in Long Island Sound, New York (authors' unpubl. data), where bacterial size is smaller in colder water (Lee \& Fuhrman 1987).

Fenchel (1982) measured ingestion and clearance rates for 6 species of heterotrophic flagellates feeding on a bacterial isolate (Pseudomonas sp.). In his study maximum ingestion rates varied from 27 to 254 bacteria flagellate $\mathrm{h}^{-1}$ and clearance from 1.4 to $79 \mathrm{nl}$ flagellate ${ }^{-1} \mathrm{~h}^{-1}$ Values for both ingestion and clearance obtained during the present study were at the low end of Fenchel's ranges (Table 3). Specific clearance, or body volumes cleared per time, is probably a better parameter for comparison of different organisms, however, and since the flagellates in the present study were generally smaller (11 to $35 \mathrm{\mu m}^{3}$ ) than the laboratory ones (20 to $200 \mathrm{um}^{3}$ ) specific clearance was nearly the same for the 2 groups. Sherr et al. (1983), working with a small $\left(30 \mathrm{\mu m}^{3}\right)$ colorless Monas sp., measured maximum clearance rates of 0.95 nl flagellate ${ }^{-1} \mathrm{~h}^{-1}$ and 3.2 $\times 10^{4}$ body volumes $\mathrm{h}^{-1}$ in their laboratory study, and Caron et al. (1985) observed values of 3.4 nl flagellate ${ }^{-1}$ $\mathrm{h}^{-1}$ and $1.9 \times 10^{4}$ body volumes flagellate ${ }^{-1} \mathrm{~h}^{-1}$ for Paraphysomonas imperforata feeding on bacteria.

In 2 experiments in Kaneohe Bay, Hawaii, where bacterial concentrations were approximately $1.3 \times 10^{6}$ $\mathrm{ml}^{-1}$ and heterotrophic flagellate abundance was about $800 \mathrm{ml}^{-1}$, Landry et al. (1984) estimated ingestion as 37.5 and 16.4 bacteria flagellate ${ }^{-1} \mathrm{~h}^{-1}$ and clearance as 29.4 and $9.5 \mathrm{nl}$ flagellate $\mathrm{h}^{-1}$. These numbers are somewhat higher than those of the present study, although the ingestion rates overlap, but may be overestimates because they assign $100 \%$ of the grazing to flagellates, whereas some other organisms, such as ciliates, may be grazing on bacteria as well (Rivier et al. 1985, Sherr \& Sherr 1987).

During the February MECCAS cruise, when bacterial growth was slower, and flagellate populations were higher, the community grazing rates (fraction of the water cleared of bacteria per day by all of the heterotrophic microflagellates) were equal to or even greater than bacterioplankton growth rates (Table 1 ). In June, however, HNAN grazing often could not balance growth; HNAN grazed 6 to $97 \%$ (mean = $22.7 \%$ ) of the daily bacterial production, as estimated by thymidine incorporation. Considering that thymidine incorporation is commonly thought to be a conservative estimate of bacterioplankton growth (Fuhrman \& Azam 1982, Newell \& Fallon 1982), the shortfall in grazing may be even greater.

Several possibilities may help to explain this discrepancy. First, bacterial populations may not be in steady state in the plume, and bacterial production may exceed grazing. Observations of the change in abundance of bacteria downstream within the plume during 2 to $3 \mathrm{~d}$ drogue deployments indicated no increase substantial enough to account for the excess of production over grazing, however. Second, some flagellates may be able to discriminate between the pigment particles and bacteria, preferentially ingesting the latter (Pace \& Bailiff 1987, Sherr et al. 1987); this would result in an underestimate of the true grazing rate for the whole community. Third, the fluorescent particle technique may be accurate for the small ( 2 to $4 \mu \mathrm{m}$ ) heterotrophic flagellates most often encountered on the filters, but may not give a good community grazing rate because 
larger, rarer forms are not included. These latter organisms include the smallest ciliates, which may be low in abundance but high in biomass, at times exceeding flagellates in the fraction of the total protozoan biomass they comprise. Their importance as bacterivores has only recently been appreciated (Rivier et al. 1985, Sherr et al. 1986, Sherr \& Sherr 1987). Finally, it has been shown that some flagellates egest material from food vacuoles when subjected to stress, including that caused by glutaraldehyde fixation. Sieracki et al. (1987) found that this could result in underestimates of particle uptake and recommended an alternative fixative (Van der Veer 1982) to avoid this problem. This effect seems to vary with species; estimates of ingestion for a chrysomonad isolate were low by more than an order of magnitude, while those of mixed populations of flagellates were low by a factor of only 2 to 3 (Sieracki et al. 1987). Our own experiments (unpubl.) with the marine chrysomonad flagellate Pseudobodo tremulans gave ingestion rates that were twice as high when Van der Veer's (1982) fixative was used instead of glutaraldehyde. Possibly, part of the discrepancy between bacterial growth and flagellate grazing for the June experiments could be explained by the fixation problem. For some stations, however, the disparity would seem to be too great to be accounted for in this way (for example, Stn 105, grazing $<8 \%$ of growth; Stn $235,<5 \%$ ).

The application of the fluorescent particle tracer technique to the measurement of bacterivory in natural communities of HNAN has led to several conclusions:

(1) Small non-pigmented flagellates do take up the particles, with body-volume specific clearance rates similar to those of laboratory cultures feeding on bacteria.

(2) Ingestion rate varies with particle concentration in a way that suggests that even at the highest bacterial densities $\left(>10^{10} l^{-1}\right)$, at least a portion of the flagellate population is not at saturation feeding levels, and that heterogeneity of populations or other factors causes rates to vary greatly at high particle concentrations.

(3) In winter, flagellate grazing, as measured by fluorescent particle uptake, could keep bacterial populations in steady state whereas in late spring grazing rates of heterotrophic flagellates were much lower than bacterial growth rates.

(4) Ciliates could at times account for a significant portion of the total grazing, when their biomass was high relative to that of the flagellates.

Overall, the technique is useful in studying bacterivory, especially in a comparative way; the disadvantage of its being time-consuming and labor-intensive may be lessened if alternative methods can be applied to the quantification of particle uptake (Gerritsen et al. 1987). In addition, more work needs to be done on laboratory isolates to determine how chemical composition and size of particles, and method of preservation, affect ingestion.

Acknowledgements. We thank Dr Hugh Ducklow and Suzanne Hill for shipboard assistance and for generously sharing their thymidine incorporation data with us. We are also indebted to Dr Thomas Malone and the other MECCAS investigators for assistance and advice. Comments by Dr $M$. Pace helped improve the manuscript. This research was funded by grant OCE 8545037 from the National Science Foundation (USA)

\section{LITERATURE CITED}

Bird, D. F., Kalff, J. (1986). Bacterial grazing by planktonic lake algae. Science 231: 493-495

Bloem, J., Bar-Gilissen, M. B., Cappenberg, T E. (1986) Fixation, counting and manipulation of heterotrophic nanoflagellates. Appl. environ. Microbiol. 52: 1266-1272

Boicourt, W C., Chao, S.-Y., Ducklow, H. W., Glibert, P. M., Malone, T. C., Roman, M. R., Sanford, L. P., Fuhrman, J. A., Garside, C., Garvine, R. W (1987). Physics and microbial ecology of a buoyant estuarine plume on the continental shelf. EOS (Trans. Am. Geophys. Un.) 68: 666

Børsheim, K. Y (1984). Clearance rates of bacteria-sized particles by freshwater ciliates, measured with monodisperse fluorescent latex beads. Oecologia (Berl.) 63: 286-288

Caron, D. A., Goldman, J. C., Andersen, O. K., Dennett, M. R. (1985). Nutrient cycling in a microflagellate food chain II. Population dynamics and carbon cycling. Mar. Ecol Prog. Ser 24: 243-254

Ducklow, H. W., Hill, S. M. (1985). The growth of heterotrophic bacteria in the surface waters of warm core rings Limnol. Oceanogr. 30: 239-259

Fenchel, T (1980a). Suspension feeding in ciliated protozoa functional response and particle size selection. Microb. Ecol. 6: 1-11

Fenchel, T. (1980b). Suspension feeding in ciliated protozoa feeding rates and their ecological significance. Microb. Ecol. 6: 13-25

Fenchel, T. (1982). Ecology of heterotrophic microflagellates II. Bioenergetics and growth. Mar. Ecol. Prog. Ser 8: 225-231

Fenchel, T (1984). Suspended marine bacteria as a food source. In: Fasham, M. J. R. (ed.) Flows of energy and materials in marine ecosystems. Plenum Press, New York, p. $301-315$

Fuhrman, J. A., Azam, F. (1982). Thymidine incorporation as a measure of heterotrophic bacterial production in marine surface waters: evaluation and field results. Mar. Biol. 66 $109-120$

Gak, D. S., Romanova, E., Romanenko, V. I., Sorokin, Y. I. (1972). Estimation of changes in number of bacteria in isolated water samples. In: Sorokin, Yu. I., Kadota, H. (eds.) Microbial production and decomposition in fresh waters. Blackwell, Oxford, p. 78-82

Gerritsen, J., Sanders, R. W., Bradley, S. W., Porter, K. G. (1987). Individual feeding variability of protozoan and crustacean zooplankton analyzed with flow cytometry. Limnol. Oceanogr. 32: 691-699

Haas, L. W. (1982). Improved epifluorescence microscopy for observing planktonic micro-organisms. Ann. Inst. Oceanogr. Paris 58(S): 261-266 
Hobbie, J. E., Daley, R. J, Jasper, S. (1977). Use of Nuclepore filters for counting bacteria by fluorescence microscopy. Appl. environ. Microbiol. 33: 1225-1228

Hollibaugh, J. T., Fuhrman, J. A., Azam, F. (1980). Radioactively labeling of natural assemblages of bacterioplankton for use in trophic studies. Limnol. Oceanogr 25: 172-181

Landry, M. R., Haas, L. W., Fagerness, V. L. (1984). Dynamics of microbial plankton communities: experiments in Kaneohe Bay, Hawaii. Mar. Ecol. Prog. Ser 16: 127-133

Lee, S., Fuhrman, J. A. (1987). Relationships between biovolume and biomass of naturally-derived marine bacterioplankton. Appl. environ. Microbiol. 53: 1298-1303

Lessard, E. J., Swift, E. (1985). Species-specific grazing rates of heterotrophic dinoflagellates in oceanic waters, measured with a dual-label radioisotope technique. Mar Biol. 87: $289-296$

McManus, G. B., Fuhrman, J. A. (1986). Bacterivory in seawater studied with the use of inert fluorescent particles. Limnol. Oceanogr 31: 420-426

Newell, S. Y., Fallon, R. D. (1982). Bacterial productivity in the water column and sediments of the Georgia (USA) coastal zone: estimates via direct counting and parallel measurement of thymidine incorporation. Microb. Ecol. 8: 33-46

Pace, M. L., Bailiff, M. D. (1987). Evaluation of a fluorescent microsphere technique for measuring grazing rates of phagotrophic microorganisms. Mar. Ecol. Prog. Ser. 40: 185-193

Rassoulzadegan, F., Sheldon, R. W (1986). Predator-prey interactions of nanozooplankton and bacteria in an oligotrophic marine environment. Limnol. Oceanogr. 31. 1010-1021

Rivier, A., Brownlee, D. C., Sheldon, R. W., Rassoulzadegan, F. (1985). Growth of microzooplankton: a comparative study of bacterivorous zooflagellates and ciliates. Mar. Microb. Food Webs 1: 51-60

Sherr, B. F., Sherr, E. B., Berman, T (1983). Grazing, growth, and ammonium excretion rates of a heterotrophic micro- flagellate fed with four species of bacteria. Appl. environ. Microbiol. 45: 1196-1201

Sherr, B. F., Sherr, E. B., Fallon, R. D. (1987). Use of monodispersed, fluorescently labeled bacteria to estimate in situ protozoan bacterivory. Appl. environ. Microbiol. 53: 958-965

Sherr, E. B., Sherr, B. F. (1987). High rates of consumption of bacteria by pelagic ciliates. Nature, Lond. 325: $710-711$

Sherr, E. B., Sherr, B. F., Fallon, R. D., Newell, S. Y. (1986). Small aloricate ciliates as a major component of the marine heterotrophic nanoplankton. Limnol. Oceanogr. 31: 177-183

Sieracki, M. E. Haas, L. W., Caron, D. A., Lessard, E. J. (1987). The effect of fixation on particle retention by microflagellates: underestimation of grazing rates. Mar. Ecol. Prog. Ser. 38: 251-258

Sokal, R. R., Rohlf, F. J. (1969). Biometry. Freeman, San Francisco

Van der Veer, J. (1982). Simple and reliable methods for the fixation, mounting and staining of small and delicate marine plankton for light microscopic identification. Mar Biol. 66: 9-14

Wikner, J., Andersson, A., Normark, S., Hagström, ^. (1986). Use of genetically marked minicells as a probe in measurement of predation on bacteria in aquatic environments. Appl. environ. Microbiol. 52: 4-8

Williams, P. J. leB. (1973). The validity of the application of simple kinetic analysis to heterogeneous microbial populations. Linznol. Oceanogr. 18: 159-165

Wright, R. T. Coffin, R. B. (1984a). Factors affecting bacterioplankton density and productivity in salt marsh estuaries. In: Klug, M. J., Reddy, C. A. (eds.) Current perspectives in microbial ecology. American Society for Microbiology, Washington, D.C., p. 485-494

Wright, R. T., Coffin, R. B. (1984b). Measuring microzooplankton grazing on planktonic marine bacteria by its impact on bacterial production. Microb. Ecol. 10: 137-149 